University of California, Hastings College of the Law UC Hastings Scholarship Repository

Faculty Scholarship

2006

\title{
Whistle Blowing: An Economic Analysis of the False Claims Act
}

Ben Depoorter

UC Hastings College of the Law, depoorter@uchastings.edu

JefDe Mot

Follow this and additional works at: http://repository.uchastings.edu/faculty_scholarship

Part of the Economics Commons

\section{Recommended Citation}

Ben Depoorter and Jef De Mot, Whistle Blowing: An Economic Analysis of the False Claims Act, 14 Sup. Ct. Econ. Rev. 135 (2006).

Available at: http://repository.uchastings.edu/faculty_scholarship/88

This Article is brought to you for free and open access by UC Hastings Scholarship Repository. It has been accepted for inclusion in Faculty Scholarship

by an authorized administrator of UC Hastings Scholarship Repository. For more information, please contact marcusc@uchastings.edu. 


\title{
UNIVERSITY of CALIFORNIA HASTINGS COLLEGE OF THE LAW
}

\section{Faculty Publications}

UC Hastings College of the Law Library

\author{
Author: Ben Depoorter \\ Source: $\quad$ Supreme Court Economic Review \\ Citation: 14 Sup. CT. Econ. Rev. 135 (2006). \\ Title: Whistle Blowing: An Economic Analysis of the False Claims Act
}

Originally published in SUPREME COURT ECONOMIC REVIEW. This article is reprinted with permission from SuPREME Court ECONOMIC REVIEW and University of Chicago Press. 


\title{
Whistle Blowing: An Economic Analysis of the False Claims Act
}

\author{
Ben Depoorter and Jef De Mot*
}

Whistle blowing, remuneration and immunity are effective tools whenever law enforcement is impeded by information asymmetries. The U.S. False Claims Act (FCA), which allows private individuals to litigate fraudulent claims on behalf of the government, has been instrumental in combating government fraud. In this paper we reveal a number of limitations and weaknesses of rewards as an alternative to punishmentbased deterrence. The main findings can be summarized as follows.

The gap between social and private incentives negatively affects the decision to file a qui tam case and the timing of whistle blowing. First, the divergence between private and social incentives of whistle blowing generates sub-optimal amounts of whistle blowing litigation in at least two instances. Whistle blowing is underprovided in all cases where free riding by the government discourages potential whistle blowers from initiating a socially valuable case. Whistle blowing is overprovided whenever qui tam private incentives conflict with social enforcement objectives. While the government weighs the wider spectrum of enforcement (the effect of an individual case on a multiple claim suit, etc.), an insider

* Ben Depoorter is Professor of Law and Economics at Ghent University and Visiting Professor at George Mason Law School and the University of Brussels (KUB). Jef De Mot is researcher at the Center for Advanced Studies of Law and Economics at Ghent University. Most of the research was conducted during Ben Depoorter's time as Fellow at the Olin Center in Law, Economics and Public Policy at Yale Law School. The Olin program is gratefully acknowledged for its assistance during those years. The authors would like to thank Susan Rose-Ackerman and two anonymous referees for helpful comments and suggestions. All remaining errors are our responsibility. 
will blow the whistle whenever his expected recovery exceeds the expected costs of litigation. This autonomy of whistle blowers to pursue claims without government involvement, weakens the government's bargaining position towards the fraudulent party. Second, whenever rewards are tied to recovery, bounties create a perverse incentive whereby fraudulent practices are not terminated at a socially optimal point in time. The potential reward race among whistle blowers cannot mitigate this effect fully because the stigma and loss of opportunities on the job market act as internal constraints on whistle blowing.

\section{INTRODUCTION}

Under the U.S. False Claims Act (FCA) individuals may litigate fraudulent claims on behalf of the government. On the basis of "qui tam"1 actions anyone who possesses evidence of fraud against federal or state programs can file a complaint. ${ }^{2}$ Recent revisions of the FCA have enhanced the financial incentives to file a lawsuit on behalf of the government.

The enlistment of citizens in law enforcement is part of a larger trend to combat corruption and fraud through rewards instead of damages. As such, the remunerative approach of the FCA finds support in recent scholarship that suggests the use of financial incentives (carrots) as an alternative to the deterrence based punishment (sticks). ${ }^{3}$

'Qui tam is derived from the Latin phrase "qui tam pro domino rege, quam pro se ipso in hoc parte sequitur," meaning "who as well for the king for himself sues in this matter." William Blackstone, Commentaries 162 \& n. 41 (William Draper Lewis ed, 1900).

${ }^{2}$ On the historical antecedents of qui tam, see Note, The Qui Tam Doctrine, 7 Tex Intl L J 415, 418 (1972). See also William Holdsworth, 4 A History of English Law 240 (Little, Brown 2d ed, 1938); Christopher C. Frieden, Comment, Protecting the Government: Interests: Qui Tam Actions Under the False Claims Act and the Government Right to Veto Settlements of those Actions, 47 Emory L J 1041, 1045 (1998); Kent D. Strader, Counterclaims Against Whistleblowers: Should Counterclaims Against Qui Tam Plaintiffs Be Allowed in False Claims Act Cases?, 62 U Cin L Rev 713, 72635 (1993); James B. Helmer Jr., How Great is Thy Bounty: Relator's Share Calculations Pursuant to the False Claim Act, $68 \mathrm{U}$ Cin L Rev 737 (2000). For an analysis of the English evolution of Qui Tam and its implications in the American context, see J. Randy Beck, The False Claims Act And The English Eradication Of Qui Tam Legislation, 78 NC L Rev 539 (2000).

${ }^{3}$ See, e.g., Robert D. Cooter and Nuno Garoupa, The Virtuous Circle of Distrust: $A$ Mechanism to Deter Bribes And Other Cooperative Crimes, The Berkeley Law \& Economics Working Papers, Vol. 2000: No. 2, Article 13 available at http://www.bepress .com/blewp/default/vol2000/iss2/art 13 . 
This Article provides an economic analysis of rewards as an alternative to punishment based deterrence. We find that bounty awards create a perverse incentive whereby fraudulent practices are not terminated at a socially optimal point in time. The potential race among whistle blowers cannot mitigate this effect fully because the stigma and loss of opportunities on the job market act as internal constraints on whistle-blowing. These constraints significantly reduce the preventive effect of qui tam litigation and reward-based approaches.

Section II provides a concise overview of the Amended Federal Claims Act. Section IIII examines the incentives for whistle blowing under the False Claims Act. Sections IV analyses the strategic options of the government to intervene in whistle blowing litigation. Section $\mathrm{V}$ analyses the gap between private and public incentives to pursue fraud under the False Claims Act. Section VI examines the timing problem inherent in whistle blowing. Section VII concludes.

\section{ENFORCING WHITE COLLAR CRIME: INFORMATION FOR DOLLARS}

In the wake of the expansion of government budgets in the eighties followed increases of fraudulent appropriations of government funds. The costs of inflated bills and false claims by government contractors, especially in defence spending ${ }^{4}$ and health care, ${ }^{5}$ amount to billions of dollars each year. Fraud is estimated at $\$ 50$ billion or one tenth of the entire federal budget and, according to some reports, rises up to $\$ 100$ billion annually. ${ }^{6}$ The recovery rates of white-collar crime are estimated at one-tenth of one percent of annual fraud. ${ }^{7}$ Government prosecutors and investigators face fraudulent practices ${ }^{8}$ by corpora-

${ }^{4}$ In the 1980's the majority of defence contractors were suspected of large scale fraud and illicit procurements. See S Rep No 99-345, at 2, reprinted in 1986 USCCAN at 5267 .

${ }^{5}$ In recent years, several false claims cases have concentrated on health care claims. These suits include recoveries against Tenet Healthcare for inflated reimbursement claims ( $\$ 4.3$ million); Northwestern University for inflated work sheets involved in research grants (\$5.5. million); San Diego Hospital Association for misrepresented costs (\$6.2 million); Mcleaod Regional Medical Center for false claims for services rendered (\$15 million), etc. See Department of Justice, Official Press Announcements available at http://www.usdoj.gov/opa/. For an overview of the largest recent recoveries, see also Taxpayers Against Fraud, The False Claims Legal Center, Statistics available at http://www.taf.org/statistics.html.

${ }^{6} \mathrm{~S}$ Rep No 99-345, at 3, reprinted in 1986 USCCAN at 5268.

${ }^{7}$ Christopher C. Frieden, Comment, Protecting the Government: Interests: Qui Tam Actions Under the False Claims Act and the Government Right to Veto Settlements of Those Actions, 47 Emory L J 1041, 1042 (1998).

${ }^{8}$ See Helmer, $68 \mathrm{U}$ Cin L Rev at 743, notes $37-38$ (cited in note 2 ) and sources cited therein. 
tions that are able to spend resources that vastly outweigh the time and assets available to government officials. ${ }^{9}$ The complexity of financial accounts, organizational realities, and jurisdictional issues complicate the enforcement of corporate criminality. Evidence problems are considerable in this area of law enforcement. ${ }^{10}$ Chain arrangement and intermediary transactions conceal the nature of business transactions and render proof of guilt beyond reasonable doubt an onerous burden. ${ }^{11}$

Traditionally, the government relies on internal audits, civil investigative demands, and the Inspector General to obtain information on organizational crime and fraud. ${ }^{12}$ By rewarding whistle blowers the False Claim Act (FCA) enlists those individuals with the best knowledge of illicit procurements from the government. ${ }^{13}$ Employees of a company or organization usually have access to information on wrongdoings that is superior to even the "best conceived government inspection system."14 Also, sometimes a degree of involvement is necessary to obtain secretive information on a fraudulent transaction. In such circumstances rewards and promises of immunity are needed to induce offenders to come forward and are best conceived as a "... price the government must pay to prosecute its prime target." ${ }^{\prime 15}$

${ }^{9} \mathrm{~S}$ Rep No $345,99^{\text {th }}$ Cong, 2d Sess 3 (1986), reprinted in 1986 USCCAN 5266, 5268.

${ }^{10}$ As a civil fraud statue, the FCA operates under the lowered evidence standard of preponderance of evidence.

11 "[B]ooks of account are confusing because the white-collar criminal wants them that way." John Braithwaite, Challenging Just Deserts: Punishing White-Collar Criminals, 73 J Crim L \& Criminology 723, 754 (1982).

${ }^{12}$ Todd B. Castleton, Comment: Compounding Fraud: The Costs of Acquiring Relator Information Under the False Claim Act and the 1993 Amendments to Federal Rules of Civil Procedure, 4 Geo Mason L Rev 327, 328 (1996).

${ }^{13}$ Increasing the probability and severity of punishment crucially depends on the expensive endeavour of gathering sufficient evidence. This supports the cost/benefit perspective of rewarding insiders for reporting wrongdoings.

${ }^{14}$ Strader, 62 U Cin L Rev at 713, 718 (cited in note 2), with reference to John L. Howard, Current Developments in Whistleblower Protection, 39 Lab L J 67 (1988) and Lewis D. Solomon and Terry D. Garcia, Protecting the Corporate Whistle Blower Under Federal Anti-Retaliation Statutes, 5 J Corp L 275, 276 (1980).

${ }^{15}$ This presents a paradox for law enforcement efforts: high expected punishments deter corruption but can only result when some offenders are promised low penalties. See, generally, Susan Rose-Ackerman, Corruption and Government: Causes, Consequences, and Reform (Cambridge, 1999). For example, granting immunity to the blameworthy is strictly necessary to combat tax offences. See John Braithwaite, Inegalitarian Consequences of Egalitarian Reforms to Control Corporate Crime, 53 Temple L Q 1127 (1980) and Adam Sutton and Ron Wild, Corporate Crime and Social Structure, in Paul Wilson and John Braithwaite, eds, Two Faces of Deviance: Crimes of the Powerless and the Powerful 101-22 (Prentice-Hall, 1978). 31 USC $\$ 3730$ (d)(3) (1994). However, there are limits to the legislator's desire to "use a rogue to catch a rogue." Id. Relators that are criminally convicted for conduct arising from a violation of the False 
To improve prosecution and recovery, the FCA invests private individuals with the ability to litigate fraudulent claims on behalf of the government against "any person who knowingly presents ... to an officer or employee of the United States Government . . . a false or fraudulent claim for payment." ${ }^{\prime 16}$

The whistle blower must file the complaint under seal and serve it upon the government. ${ }^{17}$ Within a sixty day period from filing, the government must decide whether it will intervene and take primary responsibility for the case. ${ }^{18}$ If the government decides to take on the action, the whistle blower retains the right to remain a party to the action, ${ }^{19}$ although the government is not bound by the actions of the whistle blower. ${ }^{20}$ If the government declines to intervene, the whistle blower retains the right to "conduct the action" ${ }^{21}$ but cannot dismiss the action without the consent of the court and the Attorney General. ${ }^{22}$ When the government declines to intervene leaves the burden of litigation rest upon the whistle blower but the percentage of the whistle blower's reward is higher than when the government intervenes. If the government intervenes it can government can dismiss the action notwithstanding any objections of the relator. ${ }^{23} \mathrm{Also}$, the government

Claim Act are excluded from a reward. Likewise, when a person was clearly involved in the planning and initiation of the violation of Section 3729, the court can decide, when appropriate, to reduce the share of the proceeds. Also, the automatic discovery provision of Rule 26(a) of the Amendments to the Federal rules of Civil Procedure ("FRCP") requires that a defendant, without awaiting a discovery request, discloses all the names of persons "likely to have discoverable information relevant to disputed facts alleged with particularity in the pleadings." See Castleton, 4 Geo Mason L Rev at 327,343 (cited at note 12) (in combination with Rule 11, which enable costless withdrawal from the litigation by plaintiffs, the FCA will create an influx of parasitic cases).

${ }^{16} 31$ USC $\$ 3729$. "Knowingly" is defined widely and includes submitting claims with reckless disregard for the truth or falsity of the information contained in those claims, including failure to supervise adequately employees that submit false claims to the government. 31 USC $\S 3729$ (b). See United States $v$ Entin, 750 F Supp 512 (SD Fla 1990) (bank held liable for false representation by officer acting on behalf of a Small Business Administration loan applicant).

${ }^{17} 31$ USC $\S 3730(\mathrm{~b})(2)$.

${ }^{18} 31$ USC $\S 3729(\mathrm{~b})(2)$.

1931 USC $\S 3730(\mathrm{c})(1)$ and $\S 3730(\mathrm{~b})(4 \mathrm{a})$.

${ }^{20} 31$ USC $\S 3730$ (c)(2)(A) (government can dismiss the action notwithstanding any objections of the relator); 3730 (c) (2)(B) government has the right to settle the action over the objections of the relator on the condition that the courts determines that the settlement is fair; $\S 3730(\mathrm{c})(2)(\mathrm{C})$ government has the authority to limit the relator's participation in the action.

${ }^{21} 31$ USC $\S 3730$ (c) (3). On the doctrinal foundation of qui tam standing, see Thomas R. Lee, The Standing of Qui Tam Relators Under the False Claims Act, $57 \mathrm{U}$ Chi L Rev 543 (1990).

${ }^{22} 31$ USC $\$ 3730(b)(1)$.

${ }^{23} 31$ USC $\S 3730(\mathrm{c})(2)(\mathrm{B})$. 
has the right to settle the action over the objections of the relator on the condition that the court determines that the settlement is fair. ${ }^{24}$

The 1986 amendment of the FCA increases both the percentage of the whistle blower's reward and the total amount recoverable by the government. Prior to the 1986 amendment, qui tam plaintiffs, also termed relators, might receive up to 10 percent of the recovery if the government intervened in the litigation or as much as twenty-five percent if the relator conducted the suit individually. ${ }^{25}$ The 1986 amendment increases the whistle blower's share to twenty-five percent of a maximum of thirty percent for carrying the case without government intervention ${ }^{26}$ and between fifteen and twenty-five percent of the recovery when the government intervenes. ${ }^{27}$ The amended FCA also imposes a mandatory fine of $\$ 5000-\$ 10,000$ for every false claim submitted ${ }^{28}$ The FCA creates civil liability, enabling the government to collect treble damages and a mandatory fine of 5000 to $10,000 \$$ for each false claim submitted. ${ }^{29}$

\section{THE INCENTIVE EFFECTS OF THE FCA}

By increasing the percentage of the whistle blower, the 1986 FCA amendments alter both the incentive to initiate a qui tam suit and the government's incentive to intervene in such litigation. These financial incentives induce whistle blowing by individuals who would otherwise not come forward. ${ }^{30}$

The incentive effects of the 1986 amendments are best illustrated with a numerical example. Imagine an insider complaint alleging fraud on an inflated $(\$ 20,000)$ government contract. Under the 1986 amendment treble provisions, recovery would amount to $\$ 60,000$, while the pre-1986 maximum penalty would be $\$ 40,000$. When the government intervenes and succeeds the qui tam plaintiff receives a recovery between fifteen and twenty five percent, amounting to an average personal recovery of $\$ 12,000$. Under the pre-1986 regulation there is a 10

${ }^{24} 31$ USC $\S 3730$ (c)(2)/C).

${ }^{25}$ Act of Dec 23, 1943, ch 377, 57 Stat 608 /codified as amended at 31 USC $\$ 232$ (1976).

${ }^{26} 31$ USC $\S 3730(d)(2)(1988)$.

${ }^{27} 31$ USC $\$ 3730$ (d)(1) (1988). The court determines the exact share of the qui tam plaintiff on the basis of the relator's contribution to the prosecution of the FCA suit. The share of the plaintiff can drop to ten percent of the proceeds when the case has been tried on information other than that provided by the relator. $I d$.

${ }^{28} 31$ USC $\S 3729(a)$ (1994).

${ }^{29} 31$ USC § 3729(a).

${ }^{30}$ Castleton, 4 Geo Mason L Rev at 327, 343 (cited in note 12), with reference to Elletta S. Callahan \& Terry M. Dworkin, Do Good and Get Rich: Financial Incentives for Whistleblowing and the False Claims Act, 37 Vill L Rev 273, 285 (1992). 
percent share without guarantee, amounting to $\$ 4000 .^{31}$ Where the costs to an employee or former employee of reporting organizational fraud are situated between $\$ 4,000$ and $\$ 11,999$, a rational maximizing insider will not file a qui tam suit under the old FCA but will do so under the amended FCA.

When the government declines to intervene, the burden of litigation rests with the whistle blower. If the quit tam plaintiff goes it alone, he or she will bear the entire cost of litigation if the suit is unsuccessful. Imagine that the expected cost of litigation amounts to $\$ 10,000$ and that the success rate is 50 percent. ${ }^{32}$ When the government does not intervene the whistle blower obtains $\$ 16,500$ in a successful suit with a hundred percent success rate. ${ }^{33}$ At a 50 percent success rate the whistle blower's expected benefit from litigation is $\$ 3250 .{ }^{34}$ Prior to the Amendment the share recoverable was 25 percent. With the lower damage bonus the expected value of continuing litigation drops to zero. ${ }^{35}$ Because some government officials could usually be found who had some knowledge of the fraudulent activity, ${ }^{36}$ the additional restriction of the pre-1986 FCA that the suit should not be based on information already available to the government, creates a severe discount on the whistle blower's expected reward. These hypothetical figures suggest why the qui tam provisions of the FCA remained largely dormant prior to the 1986 Amendment.

Since the 1986 Amendment, the volume of qui tam litigation has increased dramatically. Between 1986 and 1992 over 400 suits were filed. ${ }^{37}$ By 1999 more than 2000 qui tam suits have been filed. ${ }^{38}$ The recovery of misappropriated funds increased from $\$ 2$ million in $1986^{39}$

${ }^{31}$ Compare $20 \%$ of treble $\$ 60,000=12,000$ (post-1986 FCA) to $10 \%$ of double $\$ 20,000=2,000$ (pre-1986 FCA). If we assume uncertainty in receiving the bounty, as was the case prior to the amendment, the expected benefit from filing could as low as $\$ 2,000$ if we assume a fifty percent uncertainty as to the reward policy of the government.

${ }^{32}$ As we see below, large and highly successful qui tam claims are subject to government intervention. See infra Section IV.

${ }^{33} 27.5 \%$ of $100 \% .60,000$.

${ }^{34} 50 \% 16,500+50 \%-10,000=8250-5000$.

${ }^{35} 50 \%(10000)+50 \%-10000 \times 50 \% \times 50$.

${ }^{36}$ Strader, 62 U Cin L Rev at 731 (cited in note 2).

${ }^{37}$ False Claims Act Implementation: Hearing Before the Subcomm on Admin. Law and Governmental Relations of the House Comm. on the Judiciary, $101^{\text {st }}$ Cong, 2d Sess 10 (1990) (statement of Stuart M. Gerson, Assistant Attorney General, Civil Division, US Department of Justice), cited in Castleton, 4 Geo Mason L Rev at 344, footnote 124 (cited in note 12 ).

${ }^{38}$ Helmer Jr, $68 \mathrm{U}$ Cin L Rev at 744 (cited in note 2).

${ }^{39}$ This figure is calculated on the basis of total amount of $\$ 50$ billion in fraud committed against the government each year. S. Rep. No. 345, 99:h Cong, $2 \mathrm{~d}$ Sess 1 (1986), at 10-12, reprinted in 1986 USCCAN at 5266-67; False Claims Act Implementation: 
to $\$ 243$ million in the fiscal year $1995 .{ }^{40}$ The continued increase of recoveries, over $\$ 1$ billion annually in each of the past three years, ${ }^{41}$ is indicative of the effectiveness of whistle blowing under the FCA.

Recoveries result from litigation by either the DOJ or the qui tam plaintiff personally, depending on the government's decision to intervene on the basis of a whistle blower's FCA claim. The DOJ intervenes in approximately twenty percent of the qui tam cases. ${ }^{42}$ Thirtyeight percent of the cases in which the government did not intervene, were subsequently abandoned by the whistle blower or dismissed in court. The termination of eighty percent of original claims may be indicative of a number of parasitic suits, where the qui tam action is based on information contained in the original criminal indictment, newspaper accounts of prosecutions by the government ${ }^{43}$ But it also indicates a decisional divergence between the government and the private attorney general. This can be viewed from several perspectives: the government's incentive to intervene, the gap between social and private incentives to take action against the fraud and the timing of filing. This Article addresses these issues respectively in sections $\mathrm{V}$ and VI and VII. First, we explore the dynamics of litigation between the whistle blower and the DOJ.

Hearing Before the Subcomm on Admin. Law and Governmental Relations of the House Comm. on the Judiciary, $101^{\text {st }}$ Cong, 2d Sess 10 (1990) (statement of Stuart M. Gerson, Assistant Attorney General, Civil Division, U.S. Department of Justice), cited in Castleton, 4 Geo Mason L Rev at 344, footnote 124 (cited in note 2).

${ }^{40}$ Justice Department Recovers Over \$1 Billion in Qui Tam Awards and Settlements, DOJ 95542, Oct 18, 1995, available in Westlaw, 1995 WL 614572.

${ }^{41}$ In 2000 the FCA rewards has totalled 3 billion since the inception of the 1986 Amendment. See announcement by the Justice Department, February 24, 2000, available at <http://www.usdoj.gov/opa/pr/2000/February/079civ.htm. The most recent fig. ures report annual recoveries of qui tam cases pursued by the government of over $\$ 1$ billion: $\$ 1.2 .(2000), \$ 1.2(2001), \$ 1.04(2002)$. See Taxpayers Against Fraud, The False Claims Legal Center, Statistics available at http://www.taf.org/statistics.html.

${ }^{42}$ Michael Lawrence Kolis, Comment, Settling for Less: The Department of Justice Command Performance Under the 1986 False Claim Amendments Act, 7 Admin L J Am U 409, 438, n 139 (1993). Between the 1986 Amendments and 1993 more than 400 qui tam cases has been filed. False Claims Act Technical Amendments of 1992: Hearings on HR 4563 before the Subcomm on Civil and Constitutional Rights of the House Comm on the Judiciary, 102d Cong, 2d Sess 25 (1992), at 25 (Statement of Stuart M. Gerson, Assistant Attorney General, Civil Division, U.S. Department of Justice). The DOJ recovered $\$ 492$ million in the qui tam cases in which it has intervened, averaging $\$ 4$ million per case, compared to about 39,000 per case litigated by the relators alone. Id.

${ }^{43}$ The 1943 Amendments to the False Claims Act eliminated these suits by prohibiting suits based on information that is already in possession of the government when the suit is filed. Act of Dec. 23, 1943, ch 377, 57 Stat 608 (codified as amended at 31 USC $\S 232$ (1976). On the remaining problem of parasitic suits, see Castleton, 4 Geo Mason L Rev at 343 (cited in note 12). 


\section{THE INCENTIVE OF THE GOVERNMENT TO INTERVENE}

This Section explores the FCA's interesting litigation dynamic between the relator, acting as "private attorney general," and the Department of Justice (DOJ).

\section{A. Intervention by the DOJ}

When a whistle blower submits a claim, the government has 60 days to intervene and assume leadership of the case. ${ }^{44}$ When the government intervenes, the relator remains a party to the action but takes a step back and can not object to dismissals or settlements made by the government. The DOJ may dismiss the action irrespective of the relator's objections, provided the court conducts a hearing. ${ }^{45}$ Notwithstanding possible objections of the relator, the government may settle a suit if the court, upon a hearing, finds that the settlement is fair and reasonable. ${ }^{46}$ The government must inform the relator of the Government's efforts and protect his or her financial stake, for instance, by calling and cross-examining witnesses. ${ }^{47}$

On the other hand, when the government does not intervene, the relator must either initiate litigation at own expense or abandon the claim. ${ }^{48}$ The FCA Amendment reimburses litigation costs only to successful plaintiffs. ${ }^{49}$

\section{B. The Balance of Power Between the DOJ and the Whistle Blower}

If the whistle blower pursues the claim he or she can either litigate to a court verdict or settle the case. In the latter scenario, the govern-

${ }^{44} 31$ USC $\$ 3730(\mathrm{~b})(2)$.

4531 USC $\S 3730(\mathrm{c})(2)(B)$.

${ }^{46} 31$ USC $\S 3730(d)(2)$.

${ }^{47} \mathrm{~S}$ Rep No 99-345, at 25-26 (1986), reprinted in 1986 USCCAN 5266, 5290-91.

${ }^{48}$ See Act of Dec. 23, 1943, ch. 377, 57 Stat. 608 (codified as amended at 31 USC $\S$ 232 (1976). For an overview, see Gretchen L. Forney, Qui Tam Suits: Defining the Rights and Roles of the Government and the Relator Under the False Claims Act, 82 Minn L Rev 1357 (1998).

${ }^{49}$ The FCA allows the government and relators to recover litigation costs. See 31 USC $\S 3729(\mathrm{a}), 3730$ (d) (1): "Any such person shall also receive an amount for reasonable expenses which the court finds to have been necessarily incurred, plus reasonable attorneys' fees and costs. All such expenses, fees, and costs shall be awarded against the defendant." Yet, litigation entails certain costs that are not recoverable. Satellite litigation, for instance, cuts into the relator's share. See United States ex rel Taxpayers Against Fraud v General Elec Co 41 F 3d 1032, 1045-47 (6 $6^{\text {th }}$ Cir 1994); Federal Recovery Servs, Inc v United States, 72 F 3d 447, 450 (5 ${ }^{\text {th }}$ Cir 1995). 
ment and the court must consent to the dismissal of the suit. ${ }^{50} \mathrm{Cur}$ rently there exists legal uncertainty whether the government has an absolute right to block the proposed settlement between the qui tam plaintiff and the defendant. The Fifth and Ninth Circuits are split over the exact role of the government in settling FCA qui tam claims when it has chosen not to intervene in the lawsuit. ${ }^{51}$ According to Section 3730(b)(1) of the FCA an action may be dismissed only "if the court and the Attorney General give written consent to the dismissal and their reasons for consenting," ${ }^{52}$ In Killingsworth $v$. Northrop Corp..$^{53}$ the Ninth Circuit ${ }^{54}$ dismissed the government's refusal to consent to the settlement between the relator and Northrop, on the allegation that it diverted money from the False Claims Act to the plaintiff's personal claim..$^{55}$ By contrast, in Searcy v. Philips Electronics North America Corp. ${ }^{56}$ the Fifth Circuit upheld the governmental power to block settlements in straightforward manner. ${ }^{57}$

A risk exists that a settlement will reflect an opportunistic diversion from the recovery amount, shared between the government and the relator, to a personal damage claim, such as a wrongful dismissal

${ }^{50} 31$ USC $\S 3730$ (b)|(1).

${ }^{51}$ This issue is treated extensively in Christopher C. Frieden, Comment, Protecting the Government: Interests: Qui Tam Actions Under the False Claims Act and the Government Right to Veto Settlements of those Actions, 47 Emory L J 1041, 1056 (1998) (finding legislative history and the text of the FCA in favor of a right of the government to block settlements beyond the initial sixty day period).

${ }^{52}$ A literal reading of $3730 \mid$ b $\mid(1)$ leads to a veto power on behalf of the government because a suit must first be dismissed before it can be settled.

${ }^{53}$ In Killingworth a former employee of Northrop alleged that the company had inflated cost estimates related to MX missile contract proposals. See Killingworth $v$ Northrop Corp, 25 F 3d 718 (9 $9^{\text {th }}$ Cir 1994).

${ }^{54}$ In the Court's interpretation $3730(\mathrm{~b})(1)$ restricts the requirement of consent to dismissal or settlement to the initial sixty days of the suit during which $3730(\mathrm{~b})(2)$ allows the government to intervene. See id at 722 .

${ }^{55}$ The Government contended that it concerned a "sweetheart settlement" between both parties, pointing to Northrop's failure to pursue the statute of limitation defence which would have barred the wrongful termination claim. See Killingworth, $25 \mathrm{~F} 3 \mathrm{~d}$ at 718.

${ }^{56}$ Searcy v Philips Elec N Am Corp, 117 F 3d 154 (5 $5^{\text {th }}$ Cir 1997). Searcy concerns a qui tam action by Lyold T. Bortner and a private suit by five former Philips dealers which alleges that Philips fraudulently concealed its executive decision to abandon the United States electronics market while the government had purchased and leased large amounts of automation equipment relying on Philips's ongoing participation in the U.S. market.

${ }^{57}$ The parties agreed to a settlement of $\$ 1$ million in exchange for release from "all claims and counterclaims asserted in any pleadings or other filing in action, or which could have been asserted by the parties in action, arising out of the transactions or occurrences that [were] the subject matter of [the] action." Searcy, 117 F $3 \mathrm{~d}$ at 155 . 
reward, which is obtained in total by the relator. Whistle blowers can structure a settlement with a defendant so that it is heavy on attorney fees and wrongful dismissal charges while lowering the actual damages claim. As a result the relator obtains a larger share at the expense of the government. Such a tactic leaves both the relator and the defendant better off. It provides the whistle blower with a larger share of the recovery than he or she would be entitled to under the FCA, and enables the company to settle at a lower amount. The possibility of collusion between the relator and the fraudulent entity justifies some monitoring by the DOJ. In this light the Fifth Circuit in Searcy concluded that it is in the public interest to allow the government to maintain control over qui tam actions, even if it decides not to intervene..$^{58}$

However, because an unsuccessful relator bears his or her attorney fees and other expenses involved in litigating the qui tam suit, relators object that once they have taken the risk and incurred the expenses to litigate an action on an individual basis, the government should not be allowed to step forward at a later point and veto the resolution of this process. In other words, investing an absolute veto right in the government lowers the expected benefits of whistle blowing. Without reasonable limits prospective whistle blowers might be deterred ${ }^{59}$ by the prospect of hold-out behaviour by the government. ${ }^{60}$

In the remainder of this Section we take a formalized approach to the dynamics the government and the whistleblower, and more particularly, we identify the conditions where the government is most likely to intervene.

\section{A Game Theoretical Representation of Whistle Blowing Litigation}

Take the example of an employee who obtains insider information on fraudulent conduct by his or her employer/organization. The employee has three options:

1. Resort to internal whistle blowing. The agent alerts higher management or a supervising authority within the organization. The potential whistle blower's payoff $(X)$ can be positive (for instance, promotion) or negative (e.g. ostracization by fel-

${ }^{58} \mathrm{Id}$.

${ }^{59}$ Forney, 82 Minn L Rev at 1357 (cited in note 48 ).

${ }^{60}$ On the economics of hold outs, see Lloyd Cohen, Holdouts, in Peter Newman, ed, The New Palgrave Dictionary of Economics and the Law 236 (Palgrave Macmillan, 1998). 
low workers, etc.). ${ }^{61}$ The payoff of the government is $0 .{ }^{62}$ Social welfare increases whenever internal whistle blowing prevents fraudulent conduct.

2. Silence. Depending on the circumstances the payoff of the mute insider is $Y$-which can be positive (e.g. promotion) or negative (e.g. dismissal if a superior discovers the fraud and faults the employee for not detecting or alerting). The payoff of the government is 0 or negative if the fraudulent act is followed through.

3. Whistle blowing. The insider might submit a qui tam claim to the government. This leaves the government with the following options:

a. Intervene. The government can:

i. Dismiss the case: the payoff of the relator is $-Z$ /with $Z>0$ due to retaliation whenever the filing of the qui tam claim becomes public) and the payoff of the government is 0 (we assume that the costs of investigating the case are zerol

ii. Litigate: the expected payoff of the relator is dependent on the probability that the government will win the case $(p 1)$ multiplied with the relator's share $(\alpha 1 A)$ minus the relator's expected costs of whistle blowing $(-Z)$. The payoff of the government equals the probability that it will win the case $(p 1)$ multiplied with its share $((1-\alpha 1) A)$ and minus the probability that it will lose the case $(1-p 1)$ multiplied with its litigation costs $(C G){ }^{63}$

iii. Settle: the government needs to obtain at least the expected payoff of litigation. ${ }^{64}$ Thus, the minimum settlement demand equals the government's expected payoff from litigation divided by $(1-\alpha 1) .{ }^{65}$ The maximum

\footnotetext{
${ }^{61}$ See, Cora Daniels, It's a Living Hell, Fortune Magazine, April 2002: "At first the harassment was subtle. He says he was routinely denied days off and asked to cover for employees who were out. Co-workers kept their distance, and supervisors began criticizing his work. Three months later Robarge was out of a job."

${ }^{62}$ Note that we do not integrate increases of social welfare into the government's utility function.

${ }^{63}$ See, supra, footnote 51.

${ }^{64}$ We assume that cases litigate on at rates that emulate the expected payoffs of litigating the case while discounting litigation costs. See, the literature on bargaining in the shadow of the law. E.g. Robert $\mathrm{H}$. Mnookin and Lewis Kornhauser, Bargaining in the Shadow of Law: The Case of Divorce, 88 Yale L J 950 (1979).

${ }^{65}$ The exact amount will of course depend on the relative bargaining strength of each party.
} 
settlement offer equals the expected litigation losses of the firm $(p 1 A+C F)$. The relator will receive a share of $\alpha 1$ and the government retains the $(1-\alpha 1)$ share. The relator also faces the cost of starting a qui tam case $(-Z)$.

b. Decline. This leaves the whistle blower with the following options:

i. Dismiss the case: the payoff of the relator is $-Z$ and the payoff of the government is 0 .

ii. Litigate: the expected payoff of the relator is the probability that he will win the case $(p 2)$ multiplied with his share $(\alpha 2 A)$, minus the probability that he will lose the case $(1-p 2)$ multiplied with his litigation costs $(C R)$ minus the relator's cost of starting a qui tam case $(Z)$. The expected payoff of the government equals the probability that the relator will win the case $(p 2)$ multiplied with the government's share $((1-\alpha 2) A)$.

iii. Settle: the relator will demand at least the expected payoff from litigating the case. Thus, the minimum settlement demand equals the relator's expected payoff from litigation divided by $\alpha 2 .^{66}$ The government receives its share of $(1-\alpha 2)$. The maximum settlement offer equals the expected litigation losses of the firm $(p 2 A+C F)$. The relator will receive his share of $\alpha 2$ and the government its share of $1-\alpha 2$. The relator also faces the cost of starting a qui tam case $(-Z)$.

The following pay-off tree inputs the various possibilities:

The following notations apply:

$X$ represents the potential relator's expected payoff of internal whistle blowing

$Y$ represents the potential relator's expected payoff of remaining silent

$Z$ are the relator's expected costs of whistle blowing

$C_{\mathrm{G}}$ represents the litigation costs of government

$C_{\mathrm{R}}$ denotes the litigation costs of relator

$C_{\mathrm{F}}$ is the litigation costs of the accused firm

$p$ denotes the probability of winning the qui tam case where:

$p 1$ is the probability that the government will win the case;

$p 2$ is the probability that the whistle blower will win the case without government support

${ }^{66}$ Note that $Z$ is not included in this amount because it represents sunk costs. 


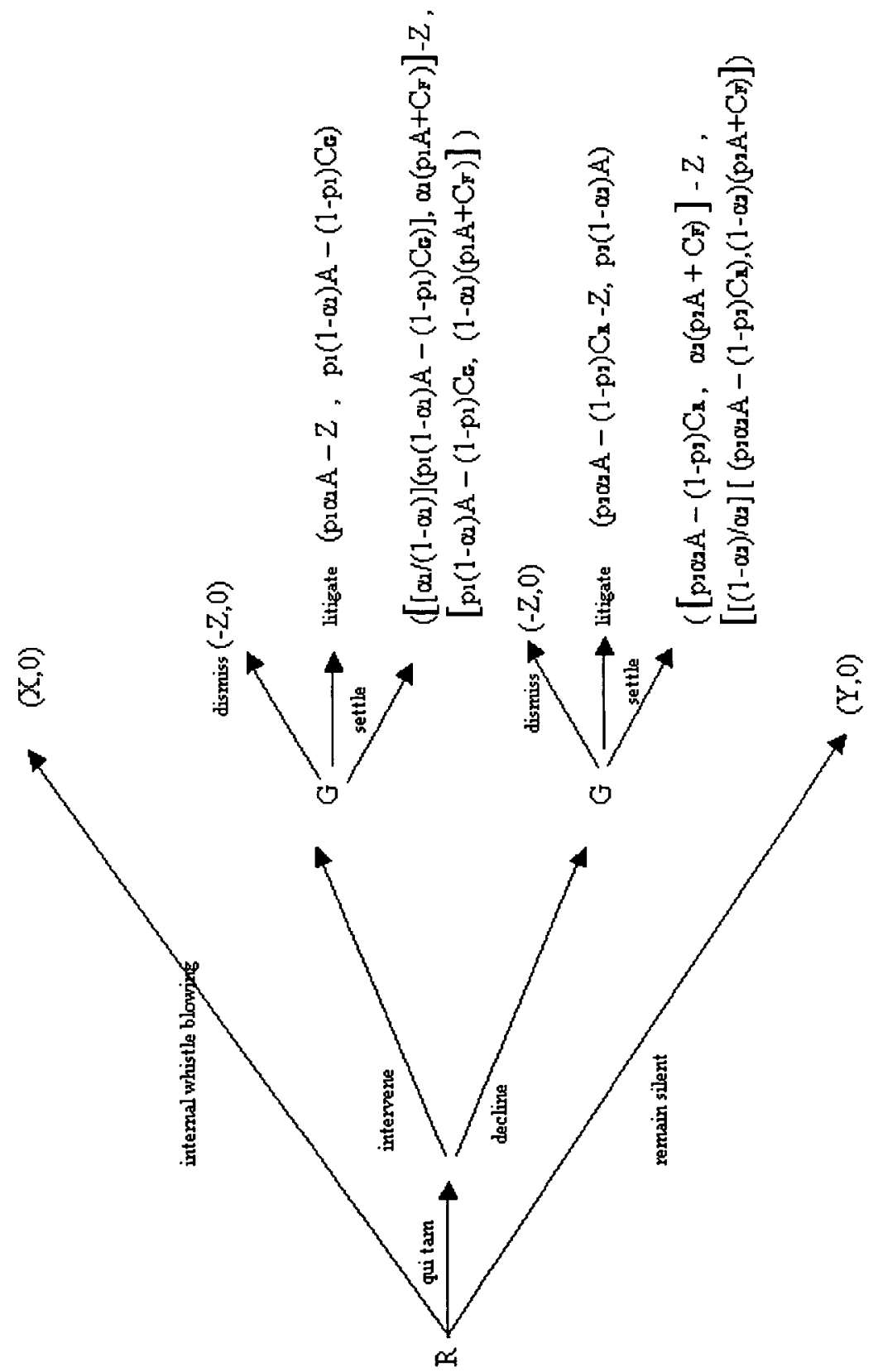

畨 
$A$ denotes the penalty or recovery resulting from the qui tam case $\alpha_{1}$ is the percentage of the recovery going to relator when government intervenes and leads the case

$\alpha_{2}$ is the percentage of recovery going to relator when the government declines and relator leads the case;

\section{The Decision to Intervene}

Now we are ready to analyze the circumstances where the government will most likely take on a qui tam case and when it will decline to intervene. To simplify, we examine the situation in which the government expects that the case will be litigated (by itself or by the relator) ${ }^{67}$ The government will intervene and litigate if:

$$
\begin{aligned}
& p 1(1-\alpha 1) A-(1-p 1) C G>p 2(1-\alpha 2) A, \text { or if } \\
& C G<[(p 1(1-\alpha 1)-p 2(1-\alpha 2)) /(1-p 1)] A
\end{aligned}
$$

Clearly, the following properties hold:

1. The higher the penalty, the higher the probability that the government will intervene and litigate $(\delta(\mathrm{RHS}) / \delta A>0)$;

2. For a given probability of winning the qui tam case, the greater the difference between the probabilities of a government court victory and a relator win, the greater the probability that the government will intervene and litigate $\left(\delta(\mathrm{RHS}) / \delta p_{1}>0\right.$ when $p_{2}=\mathrm{Cst}$ )

3. For a given percentage of recovery for the relator when the government declines, the greater the difference between the recovery percentage of the relator when the government intervenes and when the government declines, the greater the probability that the government will intervene and litigate $\left(-\delta(\right.$ RHS $) / \delta \alpha_{1}>0$ when $\alpha_{2}=$ Cst $)$;

4. When the difference between the probability of a government win and a relator win is fixed, the probability that the government will intervene and litigate increases with an increasing probability of a government win $\left(\delta(\mathrm{RHS}) / \delta p_{1}>0\right.$ when $p_{1}-p_{2}=$ Cst $)^{.6}$

${ }^{67}$ The general results are not changed if we introduce probabilities $T_{1}$ and $T_{2}$, reflecting the chance event that the case will be settled, and some parameters $W_{1}$ and $W_{2}$, that represent the bargaining strengths of the government and the relator respectively.

${ }^{68}$ More generally, the condition requires that $p 2$ does not increase too much with increases of $p l$. 
The underlying intuition is straightforward. Despite the positive expected value of litigating the case, in some cases the government will decline to intervene, since it can free ride and avoid litigation expenses by leaving litigation to the relator. ${ }^{69} \mathrm{But}$ free riding entails certain opportunity costs. When the relator litigates instead of the government, the expected award and the government's share is reduced $(p 1>p 2$ and $\alpha 1<\alpha 2)$. The costs of free riding may increase along the following three dimensions: when $A$ increases, when $p 1$ increases relative to $p 2$ or when $\alpha_{2}$ increases relative to $\alpha_{1}$.

It can also be demonstrated that the government's incentive to take on a case increases with an increasing $p 1$, even if the difference between $p 1$ and $p 2$ remains constant $(p 1-p 2=C)$. The RHS of eq. (1) becomes: $[p 1(\alpha 2-\alpha 1)+C .(1-\alpha 2) /(1-p 1)] A$. More generally, the incentive of the government to take on a case increases with increases $p 1$, when this is not accompanied by large increases of $p 2$. The partial derivative of the RHS of eq(1) is positive if:

$$
\begin{aligned}
& A\left[(1-\alpha 1)-p^{\prime} 2(1-\alpha 2)\right] !(1-p 1)+A\left[(p 1(1-\alpha 1)-(p 2)(1-\alpha 2)](1-p 1)^{-2}>0\right. \\
& \frac{A\left(1-\alpha_{1}\right)}{1-p_{1}}+\frac{A \cdot p_{1}\left(1-\alpha_{1}\right)-p_{2}\left(1-\alpha_{2}\right)}{\left(1-p_{2}\right)^{2}}>\frac{p_{2}^{\prime}\left(1-\alpha_{2}\right)}{1-p_{1}} \\
& p_{2}{ }^{\prime}<\frac{1-p_{1}}{\left(1-\alpha_{2}\right)}\left[\frac{1-\alpha_{1}}{1-p 1}+\frac{p_{1}\left(1-\alpha_{1}\right)-p_{2}\left(1-\alpha_{2}\right)}{\left(1-p_{1}\right)^{2}}\right]
\end{aligned}
$$

From the above follows that the government will take on strong cases (high $A$ and high $p 1$ ) and leave the initiative to the relator for weaker cases. However, the model also predicts that the government will intervene in some of the weakest cases. The intuitive explanation is that some cases are not worthwhile for the relator but will still be profitable to the government which has a higher probability of winning and receives a larger share of the recovery. In these cases the government will not recover anything if it declines and leaves the risk of litigation to the relator. The government will intervene not only when condition ( 1 ) is fulfilled, but also when:

$$
\left\{\begin{array}{l}
p \mathrm{l}(1-\alpha \mathrm{l}) A-(1-p \mathrm{l}) C \mathrm{G}>0 \\
p 2 \alpha 2 A-(1-p 2) C \mathrm{R}<0
\end{array}\right.
$$

${ }^{69}$ Other reasons for not intervening outside of this model are of course possible, e.g. leniency towards a cooperating firm etc. 
When rearranging the terms we obtain :

$$
\left\{\begin{array}{l}
C \mathrm{G}<[p 1 /(1-p 1)](1-\alpha 1) A \\
C \mathrm{R}<[p 2 /(1-p 2)] \alpha 2 A
\end{array}\right.
$$

From this we derive the following results and predictions:

1) The government will intervene in cases in the high-range recovery range where:

$$
C G<[(p 1(1-\alpha 1)-p 2(1-\alpha 2)) /(1-p 1)] A
$$

2) the government will decline and the relator will intervene in cases in the mid-level recovery range where:

$$
\left\{\begin{array}{l}
C \mathrm{G}>[(p 1(1-\alpha 1)-p 2(1-\alpha 2)) /(1-p 1)] A \\
C \mathrm{R}<[p 2 /(1-p 2)] \alpha 2 A
\end{array}\right.
$$

3) the government will intervene in low recovery cases in which the relator would dismiss:

$$
\left\{\begin{array}{l}
C \mathrm{G}<[p 1 /(1-p 1)](1-\alpha \mathrm{l}) A \\
C \mathrm{R}>[p 2 /(1-p 2)] \alpha 2 A
\end{array}\right.
$$

\section{PUBLIC VERSUS PRIVATE INCENTIVES OF WHISTLE BLOWING}

We are now ready to evaluate the conflict between private and social incentives of litigation with whistle blowing. In this section we identify two possible instances where divergences between private and social incentives induce a suboptimal amount of whistle blowing litigation. In one instance socially valuable claims will not be litigated because of a free rider-public good issue between the qui tam plaintiff and the government. In other circumstances, divergences between private and social enforcement objectives lead to litigation that is unwarranted from a social perspective. We examine these cases of under- and overprovision of whistle blowing litigation in turn.

\section{A. Underprovision of Litigation with Whistle Blowing}

In certain instances relators will not submit socially valuable claims because of the government incentive to free ride on these claims. 
Here we derive the conditions under which this occurs on the basis of a simple model that extends Shavell's seminal contribution on social versus private incentive to bring suit. ${ }^{70}$

Like Shavell, we use a model of a discrete nature. The firm can either decide not to commit fraud, in which case it does not receive any benefit and faces no sanction, or decide to commit fraud, in which case it receives a benefit $B$ and faces an expected sanction equal to $p_{i}\left(A+C_{j}\right)+C F$ if the government $(i=1$ and $j=G)$ or the relator $(i=2$ and $j=R$ ) sues and a sanction of zero if nobody sues. ${ }^{71}$ Furthermore, we assume that, legal expenses apart, social costs would be reduced if firms do not commit fraud $(B<L) .^{72}$ We also assume that for any sanction $A^{73}$ a percentage of firms $(\mu)$ will still commit fraud. ${ }^{74}$ Firms are thus assumed to be heterogeneous. For simplicity's sake we assume that the firm knows ex ante (before deciding whether to commit fraud) with certainty that the fraud will come to the knowledge of a potential whistleblower (in other words, there's a $100 \%$ probability of detection). Finally, we exclude the possibility of settlement. ${ }^{75}$

Suppose there is a qui tam case that is socially valuable for the government to litigate (note that it could be socially valuable or not if the relator litigates). This means that social costs are smaller when the case is filed and litigated than when it's not:

$$
\mu(C G+C F+Z+L)<L-B
$$

If the government would have no incentive to free ride, it would be willing to litigate if:

$$
p_{1}\left(1-\alpha_{1}\right) A-\left(1-p_{1}\right) C G>0
$$

and the relator would file the claim if:

$$
p_{1} \alpha_{1} A-Z>0
$$

However, the government will free ride if:

${ }^{70}$ Steven Shavell, The Social Versus The Private Incentive To Bring Suit In A Costly Legal System, 11(2) J Legal Stud 333-340(1982)

${ }^{71}$ In Shavell's model the defendant can either not engage in prevention activity (then the probability of loss 1 equals $p$ ) or engage in prevention activity (spend $x$ so that probability of loss 1 reduces to $q$ ).

${ }^{72}$ In Shavell's model it is assumed that social costs reduce with defendants' prevention activities.

${ }^{73} \mathrm{~A}$ is a financial penalty. No costs are attached to it except the trial costs.

${ }^{74}$ This assumption assures that trial costs will be incurred.

${ }^{75}$ Introducing the possibility of settlement does not lead to a qualitative difference as long as settlement costs are not equal to zero. See id at 338-39. 


$$
\left\{\begin{array}{l}
C \mathrm{G}>\left(\left(p_{1}\left(1-\alpha_{1}\right)-p 2\left(1-\alpha_{2}\right) /\left(1-p_{1}\right)\right) A\right. \\
C \mathrm{R}<(\mathrm{p} 2 /(1-p 2)) \alpha 2 A
\end{array}\right.
$$

If the government will free ride and the relator anticipates this, the relator will not file a claim if:

$$
\mathrm{p}_{2} \alpha_{2} A-\left(1-p_{2}\right) C \mathrm{R}-\mathrm{Z}<0
$$

In the following condition, a socially valuable claim will not be filed even though it would be filed if the government did not have the option to free ride (or could credibly commit not to free ride) ${ }^{76}$ on the relator's effort:

$$
\begin{aligned}
& \left\{\begin{array}{l}
\left(\left(p_{1}\left(1-\alpha_{1}\right)-p_{2}\left(1-\alpha_{2}\right) /\left(1-p_{1}\right)\right) A<C G<\left(p_{1}\left(1-p_{1}\right)\right)\left(1-\alpha_{1}\right) A\right. \\
p 2 \alpha 2 A-\left(1-p_{2}\right) C \mathrm{R}<\mathrm{Z}<\operatorname{Min}\left\{p_{1} \alpha_{1} A,(L-B) / \mu-L-C \mathrm{~F}-C \mathrm{G}\right\}
\end{array}\right. \\
& C \mathrm{R}<(p 2 /(1-p 2)) \alpha 2 A
\end{aligned}
$$

Intuitively then, a socially valuable claim, that would be filed but for government free riding, will not be filed when: 1) the trial costs of the government are so high that the government has an incentive to free ride while the trial costs are low enough that an incentive remains to pursue the case in the absence of the possibility to free ride; 2) the relator's expected costs of whistle blowing are so high that that the relator will not file the claim if it has to pursue the case itself, but small enough that the relator will file the claim if the government would pursue the case; ${ }^{77} 3$ ) the trial costs of the relator are low enough so that he or she will be willing to litigate after incurring $Z$, so the government can free ride on his effort.

\section{B. Overprovision of Whistle Blowing Litigation}

Another important difference between the positions of the government and a whistle blower relates to incentives and objectives of enforcement. ${ }^{78}$ The DOJ optimises enforcement of fraudulent

${ }^{76}$ It should be emphasized that free riding may also prevent claims with negative social value.

"Of course, the expected costs for the whistle blower must be low enough so that the social value of litigating the claim is positive.

${ }^{78}$ See generally, William M. Landes and Richard A. Posner, The Private Enforcement of Law, 4 J Legal Stud 1 (1975). 
claims over a multitude of factors. ${ }^{79}$ When deciding whether to pursue a whistle blowing claim, the DOJ weighs factors such as the allocation of time and resources relative to other cases, ${ }^{80}$ the effect of a case on ongoing and related criminal investigations, the progress in uncovering a larger fraudulent network, etc. A potential whistle blower faces different incentives altogether: whenever expected recovery exceeds the expected costs of litigation, the relator will pursue the case. When the government decides not to intervene, the relator has the right to go it alone and conduct the trail at own expense and risk.

There are several instances where social and private interests might diverge on the decision to litigate under the FCA. Sometimes the public interest is better served by leaving misconduct unprosecuted. The DOJ has an interest not simply in prosecution and punishment but also in generating goodwill to persuade companies to improve monitoring procedures. In some cases, leniency by the government will promote goodwill and better future behaviour, especially where there is an educational component. ${ }^{81}$ Indiscriminate prosecution of all offences might foster resentment and reduce motivation for future cooperation. It might be good inspectorial practice not to recommend a prosecution when the company comes forward and admits the fraudulent violation..$^{82}$ In this regard the public knowledge provisions of the FCA act as a possible safeguard.$^{83}$ Confessions will be enhanced when a company can prevent the wilful decision of private attorney generals to prosecute if the novelty aspect of the information is preempted by the company itself. This provision was introduced into the FCA with the 1943 amendment which excludes the use of informa-

${ }^{79}$ For the purposes of our analysis however we use the simplifying assumption that the government makes optimal long run allocation decisions among areas of enforcement, although its incentives may be suboptimal in deciding whether to file in a particular case. For instance, in the previous section we showed that the government can have an incentive to free ride on the relator.

${ }^{80}$ Michael Lawrence Kolis, Comment, Settling for Less: The Department of Justice Command Performance Under the 1986 False Claim Amendments Act, 7 Admin L J Am U 409, 438 (1993) (qui tam plaintiff autonomy disrupts optimal enforcement by the DOJ by forcing its private agenda upon the government).

${ }^{81}$ Braithwaite, 73 J Crim L \& Criminology at 752 (cited in note 11).

${ }^{82}$ See id /suggesting that inconsistent enforcement is beneficial when the educative role of safety inspectors outweighs the enforcement role).

${ }^{83}$ See 31 USC $§ 3730$ (e)(4)(A): "No court shall have jurisdiction over an action under this section based upon the public disclosure of allegations or transactions in a criminal, civil, or administrative hearing, in a congressional, administrative, or Government Accounting Office report, hearing, audit, or investigation, or from the news media, unless the action is brought by the Attorney General or the person bringing the action is an original source of the information." 
tion that is already in the government's possession. ${ }^{84}$ The most obvious reason why a prosecution might not be socially desirable relates to the costs of litigation. For certain offences, the social costs of litigation might not outweigh the benefits from recovery. Non-litigious methods of achieving restitution, deterrence and incapacitation are often necessary because the costs of litigating complex white collar fraud are often daunting. Therefore, the prosecution of offenders is often based on the relative costs of a case, or because cooperation is not required to retrieve information. ${ }^{85}$

The autonomy of the relator to pursue a claim individually reduces the ability of the government to negotiate favourable settlements and to weigh in other factors, such as the effect of an individual case on a multiple claim suit. Despite the DOJ's commitment not to prosecute, companies always face the possibility of litigation by an independent relator. Because the government cannot deliver a credible claim of immunity or non-prosecution, it is left with a weaker bargaining position. For example, in General Electric ${ }^{86}$ the relator successfully blocked a settlement between the DOJ and General Electric, leading the company to offer a settlement amount fifteen times over the original agreed settlement with the DOJ ${ }^{87}$ Although this type of uncertainty undercuts certain rule of law principles, ${ }^{88}$ the autonomy of private individuals can be a safeguard against corruption and collusion between the government and a private contractor. ${ }^{89}$ For instance, in General Electric the qui tam plaintiff accused the government of constructing a "sweetheart" deal and objected to the $\$ 234,000$ agreement between the DOJ and General Electric. On the day of trail General Electric upped the settlement to $\$ 3.5$ million. ${ }^{90}$

To some extent the FCA creates a regime whereby the agreement of both the DOI and the relator are strictly necessary to obtain a settle-

${ }^{84} \mathrm{~S}$ Rep No $345,99^{\text {th }}$ Cong, 2d Sess 1 (1986), at 10-12, reprinted in 1986 USCCAN at 5721-78.

${ }^{85}$ Braithwaite, 73 J Crim L Criminology at 754 (cited in note 11).

${ }^{86}$ United States v General Elec, 808 F Supp 580 (SD Ohio 1992); United States ex Rel Pedicone v Mazak Corp, 807 F Supp 1350 (SD Ohio 1992).

${ }^{87}$ See Steve France, The Private War on Pentagon Fraud, 76 ABA. J 46 (Mar 1990). See James B. Helmer, Jr. and Robert C. Neff, Jr., War Stories: A History of the Qui Tam Provisions of the False Claims Act, the 1986 Amendments of the False Claims Act, and their Application to the United States ex rel Gravitt v General Electric Co Litigation, 18 Ohio N U L Rev 35 (1991).

${ }^{88}$ John T. Boese, Why Thompson is Wrong: Misuse of the False Claims Act to Enforce the Anti-Kickback Act, 51 Ala L Rev 1, 3 (1999).

${ }^{89}$ Because officials must have discretion to promise leniency in the context of the remunerative model of enforcement, there is an endogenous element of corruption to the relation between the public official and the corporate entity.

${ }^{90}$ See supra note 73 . 
ment. Economic theory predicts that the competitive allocation of complementary parts increases overall prices. ${ }^{91}$ Since both relator and the DOJ need to approve a settlement they are complimentary monopolists in the production oft he final product, the settlement. Uncoordinated decision-making by relator and DOJ will drive up settlement prices under the amended FCA.

\section{THE TIMING OF WHISTLE BLOWING}

\section{A. Introduction}

The FCA rewards whistle blowers a fixed proportion of the recovery from a successful lawsuit. Because the whistle blower's reward is related to the recovery from the law suit, potential whistle blowers have an incentive to allow corruption to develop beyond the socially optimal point in time. The model below explores this adverse effect in more detail.

\section{B. Quit Tam Private Incentives and Social Optimum}

Without "qui tam" whistle-blowing legislation the government will base expenditures on the rate of punishment and the severity of sanctions in order to minimize the social costs of combating fraud and corruption. ${ }^{92}$ One component of the rate of punishment is the probability of detection. For any level of investment in detection, there is a probability distribution that the government will detect the fraud at or before time $t$. However, despite high expenditures on detection, there remains a low probability that the government will discover the fraud even after a considerable period of time. The question before us is to what extent the average detection time will decrease when taking into account the effect of "qui tam" whistle blowing legislation. It is straightforward that, when we assume that the amount of fraud within the firm increases over time; whistle blowers

${ }^{91}$ See, e.g., James Buchanan and Yoon J Yong, Symmetric Tragedies: Commons and Anticommons Property, 43 J L \& Econ 1-13(2000); Ben Depoorter and Francesco Parisi, Fair Use and Copyright Protection: A Price Theory Explanation, 21 (4) Intl Rev L \& Econ $453-473$ (2002). In the presence of concurrent controls on entry exercised by individual co-owners acting under conditions of individualistic competition, exclusion rights will be exercised even when the use of the common resource by one party could yield net social benefits. This is because the multiple holders of exclusion rights do not fully internalize the cost created by the enforcement of their right to exclude others. Norbert Schulz, Francesco Parisi and Ben Depoorter, Fragmentation in Property: Towards a General Model, 159 J Inst \& Theor Econ 594-613.

${ }^{92}$ Modeling the social cost function is beyond the scope of this article. 
generally do not have an incentive to come forward at the moment of detection.

We use the following notations:

$x$ : the government expenditure on detection

$p x|t|$ : the probability that the government will detect the fraud independently of the relator at or before time $t$ with a level of expenditure $x$ on detection; $\mathrm{d} p x / \mathrm{d} t>0$

$H(t)$ : the expected amount of fraud at time $t$

$B(t):$ the expected award of the relator, with $B(t)=\alpha H(t)$

For a given government expenditure on detection $\mathrm{x}$, the relator will choose the optimal point in time $t^{\star}$ to come forward and maximize his expected payoffs, as represented by the following function:

$$
\begin{aligned}
& R(t)=p x(t) \cdot 0+(1-p x(t)) \cdot B(t), \text { or } \\
& R(t)=(1-p x(t)) \cdot \alpha H(t)
\end{aligned}
$$

Independent discovery by the government, prior to the whistle blowing, preempts a qui tam action and prevents a potential whistle blower from capitalizing on his insider information. ${ }^{93}$ For the sake of simplicity, we make two additional assumptions. First, unless the government has started an official procedure, the relator is not aware of possible knowledge of the fraud by the government. In other words, the whistle blower cannot update his decision. ${ }^{94}$ Second, the relator values future values equally to present values..$^{95}$

The model illustrates the lack of urgency on behalf of the whistleblower upon discovering fraud. On the one hand, waiting increases the likelihood that the government will detect the fraud prior to whistle blowing and, consequently, the probability that the prospective whistle blower will end up empty handed. On the other hand, by waiting the total amount of fraud increases and so does the relator's proportional share of the penalty. By balancing both factors the relator determines the (privately) optimal time to come forward. The

${ }^{93}$ For modeling purposes, this assumption could be relaxed by introducing probability $\varepsilon\{0<\varepsilon<1\}$ that the relator will still receive an (perhaps smaller) award if the government already detected the fraud.

${ }^{94}$ If assumption two does not hold and the relator knows at every point in time whether the government has found out about the fraud or not, the relator will update his decision at every point in time the government did not find out about the fraud yet. This will shift the time that the relator will communicate the fraud to a later point. This assumption does not affect the point made here.

${ }^{95}$ In other words, the discount factor $=1$, and the discount rate $=0$. This assumption can be relaxed by introducing a discount factor $\delta$, with $0<\delta<1$. 
private incentives of the whistle blower thus stand in opposition to the social welfare optimum. From a social welfare maximizing viewpoint fraud is halted at the earliest stage of possible detection, ${ }^{96}$ when the damage is minimal and still reversible. In response to this effect, the government could adjust enforcement levels and reward shares to align private and social incentives. By taking into account the perverse incentives of the qui tam plaintiff, the FCA could be improved through mechanisms that punish delays in reporting or tie the reward to prevented damages.

\section{The Limits of Whistle Blowing Competition}

Recent literature advocates the use of bounties and immunity in law enforcement. When offered bounties and immunity, criminals would not be able to trust each other. Because each partner is a potential whistle blower, corruption might unravel because the necessary cooperation and trust is dissipated. ${ }^{97}$ The "first in time" and the "public disclosure" provisions of the amended FCA accommodate these proposals. ${ }^{98}$ Once a relator has filed suit, other insiders may not bring action on the same set of facts. ${ }^{99}$ Likewise, cases cannot be tried on the basis of information that is already disclosed in a public forum, unless the whistle blower proves that he or she is the original source of the information. ${ }^{100}$ Insiders will engage in a race to be the first to disclose, fearing that others will bring forward the essential information and reap the award and accompanying immunity. ${ }^{101}$

${ }^{96}$ Put differently, the social optimal amount of delay is zero.

${ }^{97}$ Robert D. Cooter and Nuno Garoupa, The Virtuous Circle of Distrust: A Mechanism to Deter Bribes and Other Cooperative Crimes, The Berkeley Law \& Economics Working Papers, Vol. 2000: No. 2, Article 13 available at http://www.bepress.com/ blewp/default/vol2000/iss2/art 13 .

${ }^{98}$ Respectively, 31 USC $\S 3730$ (e)(2)(A): “No court shall have jurisdiction over an action brought under subsection (b) against a Member of Congress, a member of the judiciary, or a senior executive branch official if the action is based on evidence or information known to the Government when the action was brought." and 31 USC $\$ 3730$ (e)(4)(A), see note 64, and 31 USC 3730 (e)(2)(A): "No court shall have jurisdiction over an action brought under subsection (b) against a Member of Congress, a member of the judiciary, or a senior executive branch official if the action is based on evidence or information known to the Government when the action was brought."

\$9 31 USC $\S 3730(b)(5)$.

10031 USC $\S 3730(\mathrm{e})(4)(\mathrm{B})$.

${ }^{101}$ In the absence of cooperation, relators would file at the earliest point as soon as there is positive expected value to blowing the whistle. Competition will drive the equilibrium to the earliest point in time. This is similar to the game theoretical prisoner's dilemma model described in the context of bribing. See Robert D. Cooter and Nuno Garoupa, The Virtuous Circle of Distrust: A Mechanism to Deter Bribes And Other Cooperative Crimes, The Berkeley Law \& Economics Working Papers, Vol 2000: No 2, Article 13 available at http://www.bepress.com/blewp/default/vol2000/iss2/art13. 
As the model in IV illustrates, there are a number of limitations to the bounty enforcement model. Due to the secrecy involved with fraud and corruption, there are not always multiple insiders that posses duplicate information. Also, the private expected benefits of whistleblowing must outweigh the costs of the insider. Despite the protection under the $\mathrm{FCA}^{102}$ and other federal protective measures, ${ }^{103} \mathrm{a}$ whistle blower faces substantial financial and other risks. Evidence thresholds ${ }^{104}$ and imperfect enforcement leave the whistle blower vulnerable to retaliation (e.g. harassment, threats of termination, suspension, non-promotion, reassignment, transfer, denial of training, withholding wages or other benefits, closer supervision and scrutiny, or pestering). ${ }^{105}$ Former employees are stigmatized and black listed on the job market as whistle blowers. ${ }^{106}$ The private costs of the whistle blower may thus prevent disclosure of insider information at the socially optimal time.

10231 USC $\S 3730(\mathrm{~h})$ (1994) provides that "any employee who is discharged, demoted, suspended, threatened, harassed, or in any other manner discriminated against in the terms and conditions of employment by his or her employer . . . is entitled to all relief necessary to make the employee whole."

${ }^{103}$ See John L. Howard, Current Developments in Whistleblower Protection, 39 Lab L J 67,69 (1988).

${ }^{104}$ In order to recover under the retaliatory discharge provisions of the FCA, the relator must prove that 1) dismissal was the result of a qui tam claim; 2) the employer knew of these actions; and 3) the employer discharged the relator because of the qui tam action. See Hopper $v$ Anton, 91 F3d 1261 (9 $9^{\text {th }}$ Cir 1996); Mikes $v$ Strauss, $889 \mathrm{~F}$ Supp 746 (S.D.N.Y. 1995); X Corp v Doe, 816 F Supp 1086 (ED Va 1993). Christopher C. Frieden, Comment, Protecting the Government:Interests: Qui Tam Actions Under the False Claims Act and the Government Right to Veto Settlements of those Actions, 47 Emory L J 1041, 1056, n 73 (1998).

${ }^{105}$ See e.g., Shawn Taylor, Whistleblowers Say Exposing An Employer Can Deal A Career Crushing Blow, Chicago Tribune, Aug 18, 2002: "Exposing gross misconduct in the workplace almost always has a price, whistleblower advocates say. Punishments range from being shunned by colleagues to termination to blacklisting. Whistleblowers have become victims of smear campaigns. Friends and family may distance themselves; some marriages don't survive the ordeal." Strader, 62 U Cin L Rev at 718 /cited in note 2), with reference to John L. Howard, Current Developments in Whistleblower Protection, 39 Lab L J (1988).

${ }^{106}$ Cora Daniels, It's a Living Hell, Fortune Magazine, April 2002: "About half of all whistleblowers get fired, half of those fired will lose their homes, and most of those will then lose their families too, says C. Fred Alford, author of Whistleblowers: Broken Lives and Organizational Power." "For every Sherron Watkins, there are 200 to 300 whistleblowers you never hear about who don't fare so well." Overall, $90 \%$ of whistleblowers can expect some kind of reprisal-public humiliation, isolation, career freezing, firing, blacklisting--from their company. "The forms of organizational harassment are limited only by the imagination," says Tom Devine, head of the Government Accountability Project, a whistleblower advocacy group. Its Whistleblower's Survival Guide is a mainstay in legal circles." See Fred Alford, Whistleblowers: Broken Lives and Organizational Power (Cornell, 2001). 
No race to disclose will occur unless the expected award for insiders increases beyond the critical threshold. As the equation below illustrates, a private individual in possession of information regarding fraud will come forward as soon as $1-P_{\left[x^{\cdot} \mid\right.}(t) B(t)>Z .^{107}$

There are several instances where a prospective whistle blower maximizes his reward by delaying a qui tam filing. The relator will need to overcome the evidence threshold. In order to obtain a stake in the recovery, the whistle blower will need to secure sufficient information that will provide him with a strong claim as to be able to maintain having "direct and independent knowledge" in order to secure the status of original source of the information, once disclosed. ${ }^{108}$ Also, the information will have to meet the requirement of "particularity."109 In accordance with Rule 9(b) the plaintiff must demonstrate (1) the time frame of the fraud; (2) the place of occurrence; (3) the content of the false misrepresentations; and (4) what has been obtained or lost as a consequence of the fraud. This provides potential whistle blowers with an incentive to wait for the fraudulent practice to develop further in order to ameliorate these evidence problems.

Secondly, the relator's share of the recovery, as determined by the judge, will be based on the strength of the information provided by the relator. ${ }^{110}$ Where the government proceeds with the action, and where the court does not find the action to be based primarily based on the disclosure of the specific information provided by the relator the court will determine the share "depending upon the extent to which the person substantially contributed to the prosecution of the action."111 Again, the timing of blowing the whistle might be prolonged if waiting increases the expected payoffs by allowing the insider to collect further evidence.

These factors indicate that the private timing for whistle blowing might be socially sub-optimal: it might be in the interest of the whistle blower to stall in order to reduce uncertainty (gathering additional evidence) and increase the expected payoff (bigger fraud provides larger remuneration), while the government incurs further losses as the fraudulent activities develop with time. This perverse effect can be reversed by expanding recovery whenever the whistle blower demonstrates that he or she attempted to stop the fraud or reported it to a

${ }^{107}$ We assume that the relator has no information on whether the government has discovered the fraud yet.

${ }^{108} 3730(\mathrm{e})(4)(\mathrm{B})$.

${ }^{109}$ Fed R Civ P 9(b).

${ }_{110} 31$ USC $\$ 3730$ (d) (1).

111 Id. 
supervisor. ${ }^{112}$ Also, the percentage could be inversely correlated with the delay in filing the claim. This could be viewed as an expansion of the court's approach in General Electric ${ }^{113}$ where a delay on coming forward reduced the percentage by two percent although the DOJ recommendation for more severe reduction. ${ }^{114}$

\section{CONCLUSION}

For law enforcement purposes corruption and fraud are hard battles. Because of the highly secretive and premeditated nature of these crimes, prime witnesses are themselves implicated or affiliated with parties to the fraudulent transaction. Promises of immunity and whistle blowing rewards are often required to resolve these information asymmetries. These insights have set a trend, both in scholarship and law enforcement practice, towards reward-based approaches (carrots), as an alternative or complement to punishment based deterrence (sticks).

Applying the U.S. False Claims Act (FCA) as an analytical framework, we provide a critical review of the efficiency limitations of whistle blowing. More specifically, the formal model developed in this contribution reveals a gap between social and private incentives in whistle blowing, both with regard to the decision to pursue litigation and the timing of whistle blowing.

First, the divergence between private and social incentives of whistle blowing generates sub-optimal whistle blowing litigation. Whistle blowing is underprovided when prospective free riding by the government discourages whistle blowers from initiating a socially valuable case. Whistle blowing is overprovided when the autonomy of whistle blowers to pursue claims without government involvement weakens

${ }^{112}$ Helmer, 62 U Cin L Rev at 773 (cited in note 2). See also, James B. Helmer, Jr., et al, False Claim Act: Whistleblower Litigation (LEXIS 2d Ed. 1999).

${ }^{113}$ United States v General Elec, 808 F Supp 580 (SD Ohio 1992); United States ex rel Pedicone v Mazak Corp, 807 F Supp 1350 (SD Ohio 1992).

${ }^{114}$ In United States $v$ General Electric a GE employee working in Israel first discovered in 1984 that US funds destined for the Israeli government were being diverted. By the time that the employee filed a qui tam action in 1990, the United States lost $\$ 41$ million over the six year period that the relator remained silent. Because of the risk to his professional and personal safety the Court refused the DO/'s request to deny the relator of a share in the recovery because action at an earlier time would have prevented much of the losses. Because the Court was sympathetic to the relator's fear for reprisals, the relator's remaining silent of the fraud caused the share to be reduced only slightly, from $25 \%$ to $22.5 \%$. United States v General Elec, 808 F Supp 580 (SD Ohio 1992); United States ex rel Pedicone v Mazak Corp, 807 F Supp 1350 (SD Ohio 1992) reported in Castleton, 4 Geo Mason L Rev at 359 (cited in note 12). 
the government's bargaining position and obstructs the government's ability to weigh in wider factors of enforcement (the effect of an individual case on a multiple claim suit, etc.).

Second, whenever rewards are tied to recovery, bounty awards create a perverse incentive whereby fraudulent practices are not terminated at a socially optimal point in time. The potential race among whistle blowers cannot mitigate this effect fully because the stigma and loss of opportunities on the job market act as internal constraints on whistle blowing.

These constraints on qui tam litigation provide a cautionary note against exclusive reliance on reward-based approaches to law enforcement. 